\title{
Growth curve for height at withers and body length of Mangalarga Marchador horses
}

\author{
Tales Jesus Fernandes ${ }^{1^{*}}$ (-) Felipe Amorim Caetano de Souza ${ }^{2}$ (i) Rafaela Aparecida Ribeiro ${ }^{3}$ (i) \\ Fabiana Oliveira Cunha ${ }^{2}(-)$ Sarah Laguna Conceição Meirelles ${ }^{2}\left(\right.$ Raquel Silva de Moura $^{2}$ (i) \\ Joel Augusto Muniz' ${ }^{1}$ 이
}

'Programa de Pós-graduação em Estatística e Experimentação Agropecuária (PPGEEA), Universidade Federal de Lavras (UFLA), 37200-000, Lavras, MG, Brasil. E-mail: tales.jfernandes@ufla.br. "Corresponding author.

${ }^{2}$ Programa de Pós-graduação em Zootecnia (PPGZ), Universidade Federal de Lavras (UFLA), Lavras, MG, Brasil.

${ }^{3}$ Médica Veterinária, Universidade Federal de Lavras (UFLA), Lavras, MG, Brasil.

ABSTRACT: This study aimed to evaluate the logistic and quadratic response plateau models to describe the growth of Mangalarga Marchador horses to identify the model that best describes growth for the variables height at withers and body length. Data were used from 230 horses aged 6 to 176 months, divided by sex and 16 age classes. All computational work was performed using $R$ statistical software. The logistic model was the best suited to express growth in height at withers and body length of male and female Mangalarga Marchadors aged 6 to 176 months. This allowed creating a table of reference values for these measurements over time based on the confidence interval of the model parameters. Estimates of height at withers obtained by the logistic model ranged from 144 to $154 \mathrm{~cm}$ in adult males and from 143 to 151 $\mathrm{cm}$ in adult females. For body length, values ranged from 146 to $156 \mathrm{~cm}$ in adult males and 143 to $156 \mathrm{~cm}$ in adult females. Females achieved stability in both height at withers and body length at earlier ages than did males.

Key words: age, cross-sectional method, horse husbandry, morphometr.

Curva de crescimento em altura na cernelha e comprimento corporal de equinos Mangalarga Marchador

RESUMO: O objetivo deste estudo foi avaliar os modelos logístico e platô de resposta quadrática na descrição do crescimento de equinos da raça Mangalarga Marchador identificando o que melhor descreve o crescimento das variáveis altura de cernelha e comprimento corporal. Foram utilizados dados de 230 equinos de 6 a 176 meses de idade que foram divididos por sexo e em 16 classes de idade. Toda a parte computacional envolvida foi realizada utilizando-se o software estatístico $R$. $O$ modelo logístico foi o mais indicado para expressar o crescimento em altura na cernelha e comprimento corporal de machos e fêmeas da raça Mangalarga Marchador. Foi criada uma tabela de valores referência para estas medidas ao longo da idade com base no intervalo de confiança dos parâmetros deste modelo. Estimativas das alturas de cernelha adultas obtidas pelo modelo logístico variaram de 144 a $154 \mathrm{~cm}$ nos machos e de 143 a $151 \mathrm{~cm}$ para fêmeas. Já em comprimento corporal os valores adultos variaram de 146 a $156 \mathrm{~cm}$ nos machos e 143 a $156 \mathrm{~cm}$ para fêmeas. As fêmeas apresentam maior precocidade do que os machos para atingir a estabilidade em ambas variáveis estudadas.

Palavras-chave: equideocultura, idade, método transversal, morfometria.

\section{INTRODUCTION}

The Mangalarga Marchador (MM) breed is originally from southern region of Minas Gerais - Brazil. These horses are characterized as light saddle horses, have a triangular head, withers height between 140 and $154 \mathrm{~cm}$ and 147 to $157 \mathrm{~cm}$ for females and males, respectively. In addition, it has a comfortable gait called "marcha", making it attractive for equestrian competitions and leisure (CABRAL et al. 2004, SANTIAGO et al., 2016).

The morphological evaluation has great relevance in the selection of animals for the breeding, since the morphological characteristics are related to the functionality of the equine species. Other authors have also verified the effect of morphology on locomotion in other breeds, such as, for example, GALISTEO et al. (1998) who verified the influence 
of height at withers on the biomechanics of the Andalusian thoroughbred animals finding a positive correlation with stride length (0.50). In the same way HOLMSTRÖM \& BACK (2013) positively correlated the height at withers with the performance of jumping horses.

These morphometric measurements indicated how the body's shape changes over time and; are therefore, essential for predicting animal growth. CARROL \& HUNTINGTON (1988) reported that horses' height at withers $(\mathrm{r}=0.75)$ and body length $(\mathrm{r}=0.62)$ were highly correlated with body weight, demonstrating the influence of morphometric variables on equine body development. At birth, a foal's height at withers is estimated to correspond to approximately $60 \%$ of the adult height and, at the end of its first year of life, to approximately $90 \%$ of the adult height (GREEN, 1969; GARCIA et al. 2011; PIMENTEL et al., 2017).

Data used to study equine growth are mostly obtained using repeated measurements for the same animal, from birth to adulthood, as demonstrated for example by studies conducted by SANTOS et al. (2007), which is known as the longitudinal method (SPERANDIO et al., 2011, ZEFERINO et al., 2003). However, this method is difficult to implement in the case of field studies because the equines grow until approximately five years of age, and breeders often sell them before they reach this age. An alternative is to use a cross-sectional method, where the variables can be collected once per individual. This methodology has been demonstrated to be effective in human (SPERANDIO et al., 2011) and equine (RIBEIRO et al., 2018; SOUZA et al., 2017; SOUZA et al., 2019) growth studies.

To better understand the relationship between morphofunctional characteristics and age, the study of animal growth curves via nonlinear models, especially logistic models, has gained prominence for analysing animal development because this method summarizes the information from the data into a set of parameters that can be interpreted and applied in daily farm management (FERNANDES et al., 2017; FREITAS, 2005; SILVEIRA et al., 2011).

Some authors suggested that modelling animal growth in two parts produces better results for capturing significant changes throughout the growth process. This method is a simpler alternative to nonlinear models because it describes the growth using a segmented (piecewise) model. Segmented models included the response plateau model, which is characterised by two segments: the first is determined by an increasing or decreasing curve up to a given point, $\mathrm{t}_{0}$, and from this point, the model assumes a constant $\mathrm{p}$ value, called a plateau, indicating stabilisation of the response (REZENDE et al., 2007, SANTANA et al., 2016.).

This research aimed to evaluate the logistic and quadratic response plateau models to describe the growth of Mangalarga Marchador horses and to identify which model best describes growth in the variables, height at withers and body length.

\section{MATERIALS AND METHODS}

The experimental data were obtained during an agricultural exhibition held in 2012 in Belo Horizonte, Minas Gerais, Brazil. The Research Ethics Committee of the Federal University of Lavras approved the study under protocol 039/12. Two hundred thirty Mangalarga Marchador (MM) animals were used (96 males and 134 nonpregnant females), 6 to 176 months of age, which were divided into 16 age classes and by sex, as described in RIBEIRO et al. (2018). Animals older than 36 months were officially registered as the Mangalarga Marchador breed.

All animals were measured following a health inspection for access to the exhibition park using a measuring stick. Height at withers was measured from the highest point of the interscapular region, located in the space defined by the $\mathrm{T} 5$ and $\mathrm{T} 6$ spinous processes, to the ground. Body length was measured between the cranial portion of the greater tubercle of the humerus and the caudal portion of the ischial tuberosity. A single examiner performed all measurements on the left side with the animal standing (four limbs on the ground and head in normal position) per the methodology described by CABRAL et al. (2004) and SANTIAGO et al. (2016). The body condition score was evaluated according to the scale proposed by CARROLL \& HUNTINGTON (1988): 0 - thin and 5 - very obese.

The variance was calculated between animals within the same age class to incorporate this variability into the parameter estimations through inverse-variance weighting. Logistic (I) and quadratic response plateau (II) nonlinear regression models were used to describe the MM horses' growth curve using the following equations:

$$
\text { I. Logistic: } \quad Y_{i}=\frac{\alpha}{1+\exp \left\{K\left(t_{i}-\beta\right)\right\}}+\varepsilon_{i}
$$

II. Quadratic response plateau:

$$
\begin{cases}Y_{i}=a+b t_{i}+c t_{i}^{2}+\varepsilon_{i}, & \text { se } t_{i} \leq t_{0} \\ Y_{i}=p+\varepsilon_{i}, & \text { se } t_{i}>t_{0}\end{cases}
$$

In equation I, " $Y$ " is the variable under study (height at withers/body length); " $\alpha$ " is the 
asymptote, or adult height/length; " $\mathrm{B}$ " is a location parameter associated with the model's inflection point (i.e., the age at which the animal transitions from accelerated to decelerated growth); " $K$ " is the model's maturity or precocity index, and the higher the $K$ value, the less time the animal will take to reach its adult size; " $t$ " is the animal's age, with $i=1,2, \ldots$., $\mathrm{n}$; and " $\varepsilon_{i}$ " is the random error, which is assumed to be random, independent, and normally distributed according to a zero-mean normal and constant variance, $\varepsilon_{\mathrm{i}} \sim \mathrm{N}\left(0, \sigma^{2}\right)$. In equation II, “ $a$ ", " $b$ " and " $c$ " are the parameters of the quadratic polynomial model, without direct practical interpretation; and $t_{0}$ is the junction point of the quadratic equation (1) with the plateau $p$, indicated in (2). This point $\left(t_{0}\right)$ was defined by the maximmun point at the quadratic equation. The terms " $Y_{i}$ ", " $t_{i}$ " and " $\varepsilon_{i}$ " have the same meaning as in equation I.

The models' parameters were estimated using the least squares method to obtain the system of normal equations (SNE). Since the SNE does not present a direct solution, the numerical Gauss-Newton algorithm was used, using an R program through the gnls and $l m$ functions of the nlme package. Models were compared, and the best model to describe the growth curve was selected based on the following goodness-of-fit indicators:

- Residual standard deviation (RSD) was calculated using the expression $R S D=\sqrt{M S E}$, with MSE being the mean squared error. The lower the RSD, the better the model fit.

- Adjusted coefficient of determination $\left(R_{a d}^{2}\right)$, obtained by $\mathrm{R}_{\mathrm{ad}}^{2}=1-\frac{(\mathrm{n}-1)\left(1-\mathrm{R}^{2}\right)}{\mathrm{n}-\mathrm{p}}$ where $\mathrm{n}$ is the number of observations, $\mathrm{p}$ is the number of parameters, and

$\mathrm{R}^{2}=1-\frac{\mathrm{sS}}{\text { SSTotal }}$, where SS is the sum of squares of the residuals and SS Total is the total sum of squares. The $R_{a d}^{2}$ values range from 0 to 1 , with a higher $R_{a d}^{2}$ indicating a better model fit.

The possible presence of residual dependence between measurements was analysed via the Durbin-Watson test, evaluating whether the residual of an observation was associated with the residual of the adjacent observations. The assumption of normality was tested via the Shapiro-Wilk test, and the assumption of residual homoscedasticity was tested using the Breusch-Pagan test.

Confidence intervals were obtained for the parameter estimates. The $95 \%$ confidence interval for the parameter, $\beta_{i}$, was defined $C I\left(\beta_{i}\right): \hat{\beta}_{i} \pm t_{(v ; 0 ; 025)} S\left(\hat{\beta}_{i}\right)$ where $\hat{\beta}_{i}$ is the estimate for parameter $\left(\beta_{i}\right) ; S\left(\hat{\beta}_{i}\right)$ is the standard error of the estimate, and $t_{(v ; 0 ; 025)}$ is the upper quantile of Student's $t$ distribution, considering $\alpha=5 \%$ and degrees of freedom, $v=n-p$. Based on these intervals, a reference table with $95 \%$ confidence limits was obtained for the morphometric measures studied. All statistical tests and estimates of the model parameters, confidence intervals, graphical adjustments, and other analyses were performed in $\mathrm{R}$ (R DEVELOPMENT CORE TEAM, 2018).

\section{RESULTS AND DISCUSSION}

At first, the parameters of two models were estimated for each variable and both sexes and the residuals were analyzed with the Shapiro-Wilk (SW), Breusch-Pagan (BP) and Durbin-Watson (DW) tests, considering 5\% significance level. It was observed that the tests were not significant for all scenarios. This fact indicated that there are no problems of violation of residual assumptions, and that the residuals showed normality, constant variances, evidencing that they were independent, like observed too by Fernandes et al. (2019) in study with three species of mammals.

For both height at withers and body length, goodness-of-fit indicators showed that the models effectively described the horse growth curve, with adjusted coefficients of determination $\left(R_{a d}^{2}\right)$ ranging from $95.79 \%$ to $96.60 \%$ for height at withers and from $97.53 \%$ to $97.57 \%$ for body length in the logistic model (Table 1). In the quadratic response plateau model, ranged from $82.70 \%$ to $88.36 \%$ for height at withers and from $77.30 \%$ to $93.06 \%$ for body length (Table 1). Thus, the logistic model was more suitable for describing the growth curve of Mangalarga Marchador horses since it obtained higher $R_{a d}^{2}$ values and lower RSD values for both sexes. This can be explained, because generally the growth curve for a characteristic does not have a linear shape and subsequently constant values as proposed by the plateau model, since the growth of the animals has a sigmoidal pattern (FREITAS, 2005). Therefore, the logistic model is more similar to the horses' true development and can better estimate the growth curve of the morphometric variables under study for both sexes as observed by several authors in studies with other horse breeds (FRALDINHO et al., 2015; MCMANUS et al., 2010; VALETTE et al., 2008).

FRALDINHO et al. (2015) found $\mathrm{R}^{2}$ values $(94.2 \%)$ similar to those obtained in the present study for the logistic model when studying height at withers of Puro Sangue Lusitano horses. The similarities between these results are likely because the Puro Sangue Lusitano breed was the foundation stallion for the Mangalarga Marchador breed (SANTIAGO 
et al., 2016). MCMANUS et al. (2010) studied animals with different Mangalarga Marchador breed biotypes (Hanoverian, Brazilian Showjumper, English Thoroughbred and Crossbred horses [Brazilian Showjumper $\times$ English Thoroughbred]) and also reported an of $95 \%$ in the logistic model for the female height at withers, which is near the value obtained here $(95.79 \%)$ for the female horses. VALETTE et al. (2008) obtained high $\mathrm{R}_{2}$ values (99\%) for English Thoroughbreds, French Trotters and Selle Français horses using the logistic model. These results demonstrated that the logistic model is the best model for describing the growth of different horse breeds. Conversely, DORNELLES et al. (2012) failed to achieve a convergence of the parameter estimates when using the logistic model to study the height at withers of Brazilian army horses.

Adult height at withers obtained by the models ranged from 147.4 to $149.6 \mathrm{~cm}$ in the logistic model 150.5 $\mathrm{cm}$ and $150.9 \mathrm{~cm}$ in the plateau model for female and male horses, respectively. For adult body length, values ranged from 149.9 to $151.4 \mathrm{~cm}$ in the logistic model and 153.1 and $155.2 \mathrm{~cm}$ in the plateau model for female and male horses, respectively (Table 1). These results revealed that the parameter, $\mathrm{p}$, which provides the adult value, was overestimated in the quadratic response plateau model relative to the values obtained for the parameter, $\alpha$, in the logistic model for both morphometric variables.

Models accurately described the horses' growth in height at withers and body length since these height values are within the range proposed by the current MM breed standard (females: $140-154 \mathrm{~cm}$ and males: $147-157 \mathrm{~cm}$ ). This also confirmed the efficiency of the cross-sectional data collection methodology for obtaining growth curves. RIBEIRO et al. (2018) reported for height at withers in MM animals, with approximately $147 \mathrm{~cm}$ for females and $149 \mathrm{~cm}$ for males, using the logistic model. SOUZA et al. (2019) also reportedsimilar values for height at withers and body length, for adult females (146.4-148.3 cm and 148.5-151.6, respectively) and for males (148.5151.8 and $150.7-154.8$, respectively). CABRAL et al. (2004) found body length values of $157.6 \mathrm{~cm}$ for males and $149.4 \mathrm{~cm}$ for females of the same breed.

Males have larger morphometric measurements than females. This growth trend may be due to the animals' physiological needs changing over time, especially their hormonal metabolism, and other factors related to sexual dimorphism, which can lead to different body development patterns and rates in both sexes (FRALDINHO et al., 2015). These differences were also reported in other Brazilian breeds, such as the Pantaneiro horses studied by SANTOS et al. (2007) and in foreign breeds such as the Quarter Horse (MOTA et al., 2010), Hanoverian and English Thoroughbred (MCMANUS et al. 2010).

Interestingly, the females exhibited higher estimated $\mathrm{K}$ than did the males for both height at withers and body length, indicating that females tend

Table 1 - Estimates of parameters and goodness-of-fit indicators for the logistic and quadratic response plateau model for describing the growth curve for height at withers and body length of male and female Mangalarga Marchador (MM) horses.

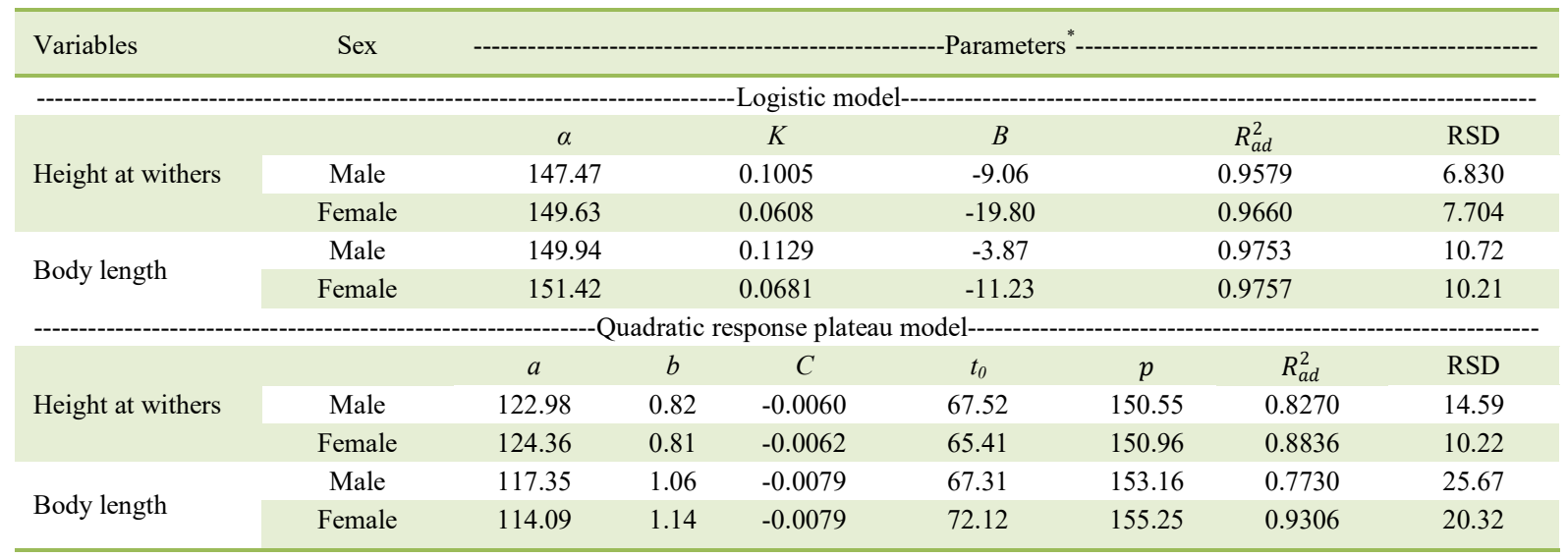

${ }^{*} \alpha$ is the asymptote, or adult height/length of the animal in centimeters; B is the inflection point of the model; $K$ is the model's maturity or precocity index; $R_{a d}^{2}$ is the adjusted coefficient of determination; RSD is the residual standard deviation; $a, b$ and $c$ are the parameters of the simple linear regression models; $t_{0}$ is the junction point of the quadratic equation with the plateau, $p$, that is, the age in months at which the animals stop growing; $p$ is the plateau constant, or the adult morphometric measure reached at time $t_{0}$, in centimeters. 
to reach maturity earlier than males (Table 1). Table 2 also evidences this precocity of females, where the lasts limits of confidence intervals for the growth curve remain mostly constant for the last studied ages (form 56 months of age) in both variables.

Other factors, such as nutrition, stressful environmental conditions, weaning time, breed, climate, geographic location, and training, may influence growth differentiation in both sexes' morphometric measurements (GONÇALVES et al., 2012; MOTA et al., 2010; SANTOS et al., 2007). Nutritional factors may be the major determinants of this precocity in females of this breed, as described by SOUZA et al. (2017), as the male and female diets usually differ, especially after weaning because most females stay on the breeding farms to breed, while the males are usually sold to generate income for the breeders. The body condition score (BCS) of the animals can also be a tool to verify some effect of the nutritional plan in the animals, as very thin or obese horses may have their growth compromised. In this study, males and females had an average BCS of $3.18 \pm 0.46$ and $3.33 \pm$ 0.59 in different studied age classes; respectively, being considered within the ideal $\mathrm{BCS}(\mathrm{BCS}=3)$ as described by Carroll and Huntington (1988).

The animals were at least six months old; thus, the abscissa of the curves' inflection point (parameter B) had negative values, suggesting that the inflection point may have occurred at an age before the first observation ( 6 months). Higher rates and homogeneous growth occurred in MM horses aged six to 24 months (Figure 1), especially in the curve generated by the logistic model (Figure $1-\mathrm{A}$ ). Several authors also obtained consistent results,

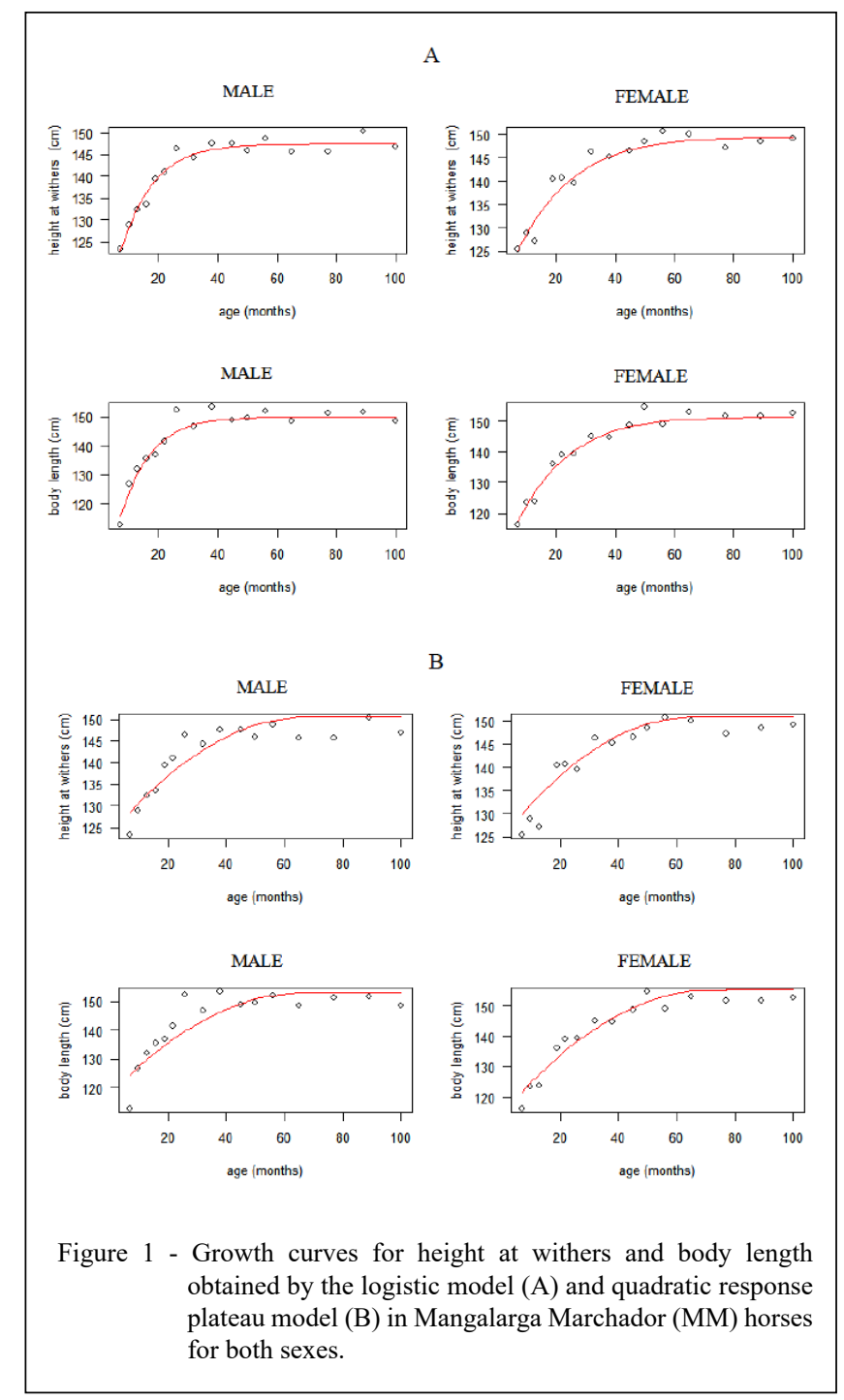

Ciência Rural, v.50, n.12, 2020. 
including VALETTE et al. (2008), and GARCIA et al. (2011), who verified higher growth rates in their studies, especially in the first years of life, which is characteristic of equines.

The curve obtained by the plateau model showed that the age at which the growth plateaued varied between 65.4 and 67.5 months for height at withers and 67.3 and 72.1 months for body length for females and males, respectively, as evidenced by the growth curve (Figure 1 - B) and by the $t_{0}$ value (Table 1 ). This indicated that the plateau model overestimates age, as suggested by SOUZA et al. (2019), who also reported this growth pattern in the Mangalarga Marchador breed.

From 24 months on, the morphofunctional variables showed greater variability, which may be justified by possible changes in nutritional and health management or more intense training methodologies since this is the age at which many horses begin rider training. Another reason is the heterogeneity intrinsic to the breed because it is still considered a new breed compared with other horse breeds (SANTIAGO et al., 2016).
To follow the animal development, table 2 provides the reference values, with lower and upper limits to the $95 \%$ confidence level for the growth curve in height at withers and body length of Mangalarga Marchador horses of both sexes along the age, based on the logistic model estimates. Animals of a certain age are expected to have measurements within the limits of their age indicated in table 2 . At approximately 60 months of age, the logistic model's growth curve stabilised in both sexes for height and length (Figure $1 \mathrm{e}$ table 2). That is more evident in female.

\section{CONCLUSION}

The logistic model is the best predictor growth in height at withers and body length in male and female Mangalarga Marchador horses from 6 to 176 months of age. The growth in morphometric measurements was more intense and homogeneous at six to 24 months of age in the Mangalarga Marchador horses, stabilising at approximately 60 months of age in both sexes. Females achieved stability in both height and body length at earlier ages than males.

Table 2 - Lower (LL) and upper (UL) limits of the 95\% confidence interval for logistic model growth curves for height at withers (cm) and body length $(\mathrm{cm})$ of the Mangalarga Marchador breed in both sexes.

\begin{tabular}{|c|c|c|c|c|c|c|c|c|}
\hline \multirow[t]{3}{*}{ Age } & \multicolumn{4}{|c|}{ 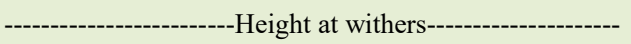 } & \multicolumn{4}{|c|}{------------------------------Body length--------------------------- } \\
\hline & \multicolumn{2}{|c|}{--------------Male------------- } & \multicolumn{2}{|c|}{----------Female---------- } & \multicolumn{2}{|c|}{------------Male----------- } & \multicolumn{2}{|c|}{---------------Female-------------- } \\
\hline & LL & UL & LL & UL & LL & UL & LL & UL \\
\hline 7 & 120.39 & 129.86 & 119.18 & 126.82 & 112.79 & 122.25 & 109.51 & 122.44 \\
\hline 10 & 123.90 & 133.37 & 124.73 & 132.38 & 117.87 & 127.33 & 117.59 & 130.51 \\
\hline 13 & 126.98 & 136.46 & 129.17 & 136.82 & 122.34 & 131.80 & 124.06 & 136.99 \\
\hline 16 & 128.56 & 138.47 & 132.66 & 140.31 & 126.59 & 136.78 & 129.11 & 142.04 \\
\hline 19 & 131.99 & 141.16 & 135.36 & 143.01 & 129.59 & 139.05 & 132.94 & 145.87 \\
\hline 22 & 133.99 & 143.45 & 137.42 & 145.07 & 132.46 & 141.92 & 135.81 & 148.74 \\
\hline 26 & 136.20 & 145.67 & 139.42 & 147.07 & 135.61 & 145.07 & 138.51 & 151.44 \\
\hline 32 & 138.75 & 148.22 & 141.31 & 148.96 & 139.14 & 148.60 & 140.91 & 153.84 \\
\hline 38 & 140.57 & 150.04 & 142.36 & 150.01 & 141.59 & 151.05 & 142.16 & 155.09 \\
\hline 45 & 142.04 & 151.52 & 143.01 & 150.65 & 143.48 & 152.94 & 142.87 & 155.80 \\
\hline 50 & 142.78 & 152.25 & 143.26 & 150.91 & 144.39 & 153.85 & 143.13 & 156.06 \\
\hline 56 & 143.42 & 152.89 & 143.43 & 151.08 & 145.15 & 154.61 & 143.29 & 156.23 \\
\hline 65 & 144.04 & 153.51 & 143.56 & 151.21 & 145.85 & 155.31 & 143.41 & 156.33 \\
\hline 77 & 144.48 & 153.95 & 143.62 & 151.27 & 146.31 & 155.77 & 143.45 & 156.38 \\
\hline 89 & 144.69 & 154.16 & 143.64 & 151.29 & 146.52 & 155.98 & 143.47 & 156.40 \\
\hline 100 & 144.79 & 154.26 & 143.65 & 151.30 & 146.61 & 156.07 & 143.47 & 156.40 \\
\hline
\end{tabular}




\section{ACKNOWLEDGEMENTS}

We thanks to veterinarian José Carlos Magalhães, the Horse Breeding Research Center of UFLA, the Postgraduate Programme in Animal Science of UFLA, the Postgraduate Programme in Agricultural Statistics and Experimentation of UFLA, the Fundação de Amparo à Pesquisa do Estado de Minas Gerais (FAPEMIG), the Coordenação de Aperfeiçoamento de Pessoal de Nível Superior (CAPES) and Conselho Nacional de Desenvolvimento Científico e Tecnológico (CNPq) for the support provided for this study.

\section{DECLARATION OF CONFLICT OF INTERESTS}

The authors declare no conflict of interest. The founding sponsors had no role in the design of the study; in the collection, analyses, or interpretation of data; in the writing of the manuscript, and in the decision to publish the results.

\section{AUTHORS' CONTRIBUTIONS}

All authors contributed equally for the conception and writing of the manuscript. All authors critically revised the manuscript and approvedthe final version.

\section{REFERENCES}

CABRAL, G. C. et al. Morphometric evaluation of Mangalarga Marchador horses: linear measures. Revista Brasileira de Zootecnia, v.33, n.4, p.989-1000, 2004. Available from: <http:// www.scielo.br/pdf/rbz/v33n4/22095.pdf $>$. Accessed: Oct. 10, 2019. doi: 10.1590/S1516-35982004000400019.

CARROLL, C. L.; HUNTINGTON, P. J. Body condition scoring and weight estimation of horses. Equine Veterinary Journal, v.20, n.1, p.41-45, 1988. Available from: <https://beva.onlinelibrary.wiley.com/ doi/abs/10.1111/j.2042-3306.1988.tb01451.x>. Accessed: Jun. 01, 2018. doi: 10.1111/j.2042-3306.1988.tb01451.x.

DORNELLES, M. A. et al. Genetic parameters and genetic and phenotypic trends of performance traits of equines from the Brazilian Army, Revista Brasileira de Zootecnia, v.41, n.6, p.1419-1425, 2012. Available from: <http://www.scielo.br/scielo. php?script $=$ sci arttext\&pid $=$ S1516-35982012000600015>. Accessed: Jun. 28, 2016. doi: 10.1590/S1516-35982012000600015.

FERNANDES, T. J. et al. Double sigmoidal models describing the growth of coffee berries. Ciência Rural, v.47, n.8, e20160646, 2017. Available from: <http://www.scielo.br/scielo. php?pid=S0103-84782017000800401\&script $=$ sci_abstract $>$. Accessed: Aug. 02, 2019. doi: 10.1590/0103-8478cr20160646.

FRALDINHO, M. J. et al. Growth and development of the Lusitano horse managed on grazing systems. Livestock Science, v.12, p.1871-1413, 2015. Available from: <http://dx.doi.org/10.1016/j. livsci.2015.06.006>. Accessed: Aug. 02, 2015. doi: 10.1016/j. livsci.2015.06.006.

FREITAS A. R. Growth curves in animal production. Revista Brasileira de Zootecnia, v.34, n.3, p.786-795, 2005. Available from: $<$ http://www. scielo.br/pdf/rbz/v34n3/a10v34n3>. Accessed: Nov. 10, 2014. doi: 10.1590/S1516-35982005000300010.
GALISTEO, A. M. et al. The influence of speed and height at the withers on the kinematics of sound horses at the handled trot. Veterinary Research Communication, v.22, p.415-423, 1998. Available from: <https://pubmed.ncbi.nlm.nih.gov/9810638/>. Accessed: Jul. 02, 2020. doi: 10.1023/a:1006105614177.

GARCIA, F. P. S. et al. Growth and development rates in thoroughbred foals in Bagé-Brazil. Revista Portuguesa de Ciências Veterinárias, v.106, p.43-46, 2011. Available from: <http://www.fmv.ulisboa.pt/spcv/PDF/pdf12_2011.old/43-46. pdf $>$. Accessed: Mar. 25, 2015.

GONÇALVES, R. W. et al. Effect of inbreeding on morfhometric traits in Mangalarga Marchador horses. Arquivo Brasileiro de Medicina Veterinária e Zootecnia, v.64, n.2, p.419-426, 2012. Available from: <http://www.scielo.br/pdf/abmvz/v64n2/ a23v64n2.pdf>. Accessed: Mar. 12, 2015. doi: 10.1590/S010209352012000200023.

GREEN, D. A. A study of growth Rate in Thoroughbred Foals. British Veterinary Journal, v.125, n.10, p.539546, 1969. Available from: <https://doi.org/10.1016/S00071935(17)48714-8>. Accessed: Mar. 12, 2015. doi: 10.1016/ S0007-1935(17)48714-8.

HOLMSTRÖM, M.; BACK, W. The effects of conformation. In: BACK, W.; CLAYTON, H. M. (Ed.) Equine locomotion. London: Elsevier, 2013. Cap.11, p.229-244.

MCMANUS C. M. et al. Nonlinear growth curves for weight and height in four genetic groups of horses. Ciência Animal Brasileira, v.11, n.1. p.80-89, 2010. Available from: <https:// doi.org/10.5216/cab.v11i1.5400>. Accessed: Sep. 17, 2015. doi: 10.5216/cab. v11i1.5400.

MOTA, M. D. S. et al. Avaliação do crescimento em potros da raça Quarto de milha. Revista electrónica de Veterinaria. v.11, n.1, p.1-10, 2010. Available from: <https://www.redalyc.org/articulo. oa? id=63613103008>. Accessed: Mar. 27, 2018.

PIMENTEL, A. M. H. et al. Gender on the growth of Criollo foals from birth to three years of age. Ciência Rural, v.47, n.1, e20150989, 2017. Available from: <http://www.scielo.br/scielo. php?script $=$ sci_arttext\&pid $=$ S0103-84782017000100651>. Accessed: May, 07, 2018. doi: 0.1590/0103-8478cr20150989.

R DEVELOPMENT CORE TEAM. R: a language and environment for statistical computing. $R$ Foundation for Statistical Computing. Vienna: $\mathrm{R}$ Foundation for Statistical Computing, 2018. Available from: <http://www.r-project.org $>$. Accessed: Jun. 12, 2018.

REZENDE, D. M. L. C. et al. Ajuste de modelos de platô de resposta para a exigência de zinco em frangos de corte. Ciência e Agrotecnologia, v.31, n.2, p.468-478, 2007. Available from: $<$ http://www.scielo.br/scielo.php?script=sci_arttext\&pi$\mathrm{d}=\mathrm{S} 1413-70542007000200030>$. Accessed: Jun. 07, 2018. doi: 10.1590/S1413-70542007000200030.

RIBEIRO, R. A. et al. Curva de crescimento em altura na cernelha de equinos da raça Mangalarga Marchador considerando-se heterocedasticidade. Arquivo Brasileiro de Medicina Veterinária e Zootecnia, v.70, n.1, p.272-278, 2018. Available from: <http:// www.scielo.br/scielo.php?script=sci_abstract\&pid $=$ S010209352 018000100272\&lng=en\&nrm=iso\&tlng=pt $>$. Accessed: Feb. 09, 2019. doi: 10.1590/1678-4162-9322. 
SANTANA, T. J. S. et al. Modelo von Bertalanffy com resposta em platô para descrever curvas de crescimento de bovinos de corte. Revista Brasileira de Biometria, v.34, n.4, p.646-655, 2016. Available from: <http://www.biometria.ufla.br/index.php/BBJ/ article/view/254>. Accessed: Oct. 08, 2018.

SANTIAGO, J. M. et al. Evolution of morphometric measures in the Mangalarga Marchador breed. Revista Caatinga, v.29, n.1, p.191-199, 2016. Available from: <http://www.scielo.br/pdf/rcaat/ v29n1/1983-2125-rcaat-29-01-00191.pdf $>$. Accessed: Jan. 28, 2018. doi: 10.1590/1983-21252016v29n122rc.

SANTOS, S. A. et al. Monitoramento do desenvolvimento de cavalos pantaneiros por meio de curvas de crescimento. Archivos de zootecnia, vol. 56, supl. 1, p.647-654, 2007. Available from: $<$ http://www.uco.es/organiza/servicios/publica/az/php/img/web/0 10853 47MonitoramentoSantos.pdf>. Accessed: Dec. 09, 2015

SILVEIRA, F. G. et al. Análise de agrupamento na seleção de modelos de regressão não lineares para as curvas de crescimento de ovinos cruzados. Ciência Rural, v.41, p.692-698, 2011. Available from: $\quad<$ http://www.scielo.br/pdf/cr/v41n4/a928cr3957.pdf> Accessed: Jul. 02, 2016.

SOUZA, F. A. C. et al. Nonlinear modeling growth body weight of Mangalarga Marchador horses. Ciência Rural, v.47, n.4 e20160636, 2017. Available from: <https://doi.org/10.1590/0103- 8478cr20160636. Accessed: Dec. 16, 2018. doi: 10.1590/0103$8478 \mathrm{cr} 20160636$.

SOUZA, F. A. C. et al. Morphometric characteristics of Mangalarga Marchador horses determined by non-linear models. Pesquisa Agropecuária Brasileira, v.54, e01145, 2019. Available from: <https://doi. org/10.1590/S1678-3921.pab2019.v54.01145>. Accessed: Jan. 20, 2020. doi: 10.1590/s1678-3921.pab2019. v54.01145.

SPERANDIO, N. et al. Comparison of the nutritional status during childhood with different growth curves. Revista de Nutrição, v.24, n.4, p.565-574, 2011. Available from: <http:// dx.doi. org/10.1590/S1415-52732011000400005>. Accessed: Jul. 14, 2016. doi: 10.1590/S1415-52732011000400005.

VALETTE, J. P. et al. Use of linear and non-linear functions to describe the growth ofyoung sport- and race-horses born in Normandy. Animal, v.2, n.4, p.560-565, 2008. Available from: $<$ https://www.ncbi.nlm.nih.gov/pubmed/22443570>. Accessed: Jul. 19, 2017. doi: 10.1017/S1751731107001462.

ZEFERINO, A. M. B. et al. Monitoring growth . Jornal de Pediatria, v.79, supl.1, p.23-32, 2003. Available from: $<$ http://www.scielo.br/pdf/\%0D/jped/v79s 1/v79s 1 a 04. pdf $>$. Accessed: Aug. 20, 2016. doi: 10.1590/S002175572003000700004. 